\title{
Khiyār (hak untuk memilih) dalam Transaksi On-Line: Studi Komparasi antara Lazada, Zalara dan Blibli
}

\author{
Muhammad Majdy Amiruddin \\ Alumnus Master Muamalat Administration (MMA), \\ Universiti Sains Islam Malaysia (USIM) \\ E-mail:majdy@gmail.com
}

\begin{abstract}
ABSTRAK
Khiyar atau pilihan adalah hak yang diberikan kepada pembeli dan penjual apakah akan melanjutkan atau membatalkan transaksi mereka. Dalam transaksi online, konsumen tidak memiliki kontak langsung dengan pedagang dan tidak bisa dengan mudah memverifikasi kualitas barang, sehingga menciptakan situasi di mana para pelaku transaki tidak pada kekuatan tawar yang sama. Oleh karena itu, penerapan khiyar akan membantu dalam melindungi hak-hak konsumen di dunia maya. Tujuan dari artikel ini adalah untuk menganalisis jenis khiyar dan aplikasinya terhadap bisnis online yang sedang menjamur di Indonesia serta membandingkannya terhadap lazada, zalora dan blibli. Hasil dari penelitian ini menunjukkan bahwa khiyar aib diaplikasikan oleh ketiga situs tersebut, sedangkan khiyar ru'yah hanya diaplikasikan oleh lazada. Metodologi yang digunakan dalam penelitian ini adalah metode kualitatif yang bersumber pada rujukan-rujukan yang sesuai dengan melakukan pendekatan komparatif kepada ketiga situs tersebut.
\end{abstract}

Kata Kunci: Jual beli, Khiyar, Bisnis On-line

\section{Pendahuluan}

Teknologi berkembang dengan kecepatan yang sangat cepat dan transaksi online terutama penjualan barang melalui internet telah menghasilkan kebutuhan untuk intervensi hukum dalam ranah tertular dengan tujuan utama perlindungan konsumen. Kemudahan mengakses dan mengirimkan informasi melalui internet telah menarik konsumen dan bisnis untuk melakukan transakasi online atau $e$ commerce. Seseorang dapat melakukan transaksi bisnis dan terhubungnya setiap individu dalam hitungan detik selama internet dalam keadaan 'on-line', baik melalui laptop atau computer maupun melalui smartphone. Dengan segala 
kelebihan dan manfaat dari perkembangan itu, hal itu juga telah memberikan resiko dengan adanya situasi yang meragukan dan ketidakpastian mengenai perlindungan konsumen. Ahli hukum Islam (fuqaha') telah menyarankan sejumlah perangkat untuk yang memberikan kenyamanan bagi pihak-pihak yang bertransaksi guna menghindari kecurangan yang terjadi dalam transaksi. Perangkat ini memberikan kesempatan untuk merenungkan transaksi dan mencabut kesepakatan dalam transaksi bila terdapat ketidakcocokan setelah objek transaksi diterima. Dalam hukum Islam, perangkat ini disebut khiyarat (jamak dari kata khiyar). Khiyar ini dirancang untuk menjaga keseimbangan dalam transaksi dan untuk melindungi pihak yang rawan mengalami kerugian. Khiyar merupakan tindakan pencegahan yang melindungi terhadap ketidakcocokan pada barang, yang berasal dari kurangnya pengetahuan tentang kualitas produk dan kurangnya kualitas yang diinginkan. Validitas dasar opsi ini dibuktikan dengan Sabda Rasulullah Saw, yang menyatakan,

"Jika pihak kontraktor berbicara kebenaran dan mengungkapkan cacat barang maka kontrak akan bermanfaat bagi keduanya. Jika mereka tidak berbicara kebenaran dan menyembunyikan cacat barang mereka akan [Allah akan] mengurangi manfaat dari transaksi (HR. Bukhari).

Didalam Al-Qur'an juga telah diberikan hak untuk opsi memilih tersebut kepada individu dalam kaitannya dengan perdagangan, transaksi sipil dan kontrak (QS. Al-Baqarah[2]: 275)

Salah satu cara untuk melindungi hak-hak konsumen dalam lingkup virtual adalah dengan memberikan konsumen hak untuk melakukan khiyarat untuk membatalkan kontrak. Khiyar memberikan pilihan dalam jangka waktu tertentu setelah kesimpulan dari tawar-menawar yang memungkinkan untuk salah satu pihak untuk membatalkan transaksi. Zalora, Lazada dan Blibli ada tiga situs terbesar yang menawarkan jual beli online (e-commerce transaction) di Indonesia. Ketiga situs inilah objek studi komparatif terhadap penerapan khiyar yaitu ketentuan yang mendasari bolehnya pembeli melakukan pengembalian barang yang telah diterima. 


\section{Transaksi Online (e-commerce) dalam Islam}

Pertumbuhan e-commerce dalam beberapa tahun terakhir telah menghasilkan keragaman yang cukup besar dan kompleksitas dalam struktur dan aplikasi. Ecommerce mengacu pada penggunaan teknologi informasi dan komunikasi untuk jaringan kegiatan ekonomi dan proses, untuk mengurangi informasi yang berkaitan dengan biaya transaksi untuk mendapatkan keuntungan informasi (Thomas R. Leinbach \& Stanley D. Brunn, 2001). Dari sudut pandang Islam, ecommerce tidak berbeda dengan konsep perdagangan konvensional, tetapi disertai dengan aturan dan kewajiban yang harus selaras dengan kebutuhan dan prinsipprinsip Islam.

Ajaran fundamental Islam berasal dari empat sumber; Al-Quran dan Sunnah, analogi (qiyas), dan konsensus ulama' (ijma). Al-Quran memandang kehidupan manusia sebagai proses yang berkesinambungan. Seseorang harus bekerja untuk sukses dan kenyamanan tidak hanya untuk dunia ini tetapi juga untuk akhirat. Oleh karena itu, Al-Quran tidak hanya mengizinkan manusia untuk terlibat dalam segala macam pekerjaan produktif (seperti bisnis), tetapi juga berbagai kewajiban umat Islam. Dalam konsep bisnis Islam, umat Islam harus sangat setia dan takut akan Allah dalam setiap jenis usaha atau perdagangan. Sebagaimana Allah Swt berfriman,

“... Allah telah menghalalkan perdagangan dan mengharamkan riba. Orangorang yang telah sampai kepadanya larangan dari Tuhannya, lalu terus berhenti (dari mengambil riba), maka baginya apa yang telah diambilnya dahulu(sebelum datang larangan); dan urusannya (terserah) kepada Allah. Orang yang kembali (mengambil riba), maka orang itu adalah penghuni-penghuni neraka; mereka kekal di dalamnya”. (QS. Al-Baqarah[2]: 275).

Untuk kesejahteraan Muslim yang bersangkutan, ajaran Islam tersebut selaras dalam sektor perdagangan sebagai sumber utama kekayaan dan kekuatan angin roda perekonomian. Dalam hal ini, Al-Quran penuh dengan banyak referensi dalam mendukung perdagangan dan kegiatan-kegiatan komersial. Misalnya, ayatayat Al-Quran yang mendukung relevan dengan pernyataan ini adalah: "Celakalah Al-Mutaffifin [mereka yang memberi kurang dalam ukuran dan berat (mengurangi hak orang lain)]" (QS. Al-Muthaffifin[83]: 1). 
Dalam sebuah wawancara dengan Ustaz Mustafa Omar (Norazlina Zainul et. al, 2004 ), beliau menyebutkan bahwa konsep perdagangan dalam Islam secara umum tidak bertentangan E-Commerce; bahkan mendorong E-Commerce sebagai salah satu cara baru melakukan bisnis. Dijelaskan pula bahwa secara tradisional, bisnis dilakukan secara lisan tatap muka tetapi hari kedua pihak kontraktor yang terhubung bersama-sama melalui komputer. Namun, (Hussin, 2002) menambahkan bahwa apa yang banyak dari persetujuan dalam melakukan ECommerce adalah perspektif moral yang mengarah ke pedagang lebih akuntabel dan bertanggung jawab. Dengan demikian, beberapa isu-isu Syariah dapat direferensikan sambil membahas beberapa hal yang terkait dengan prinsip-prinsip etika dalam bisnis syariah.

Secara umum, Al-Quran mengungkapkan dua persyaratan untuk keabsahan transaksi yang diberikan; yaitu, dibolehkan dan tidak berbahaya. Kebolehan berarti bahwa komoditas dan layanan tersebut harus diperbolehkan oleh Syariah (hukum Islam); sementara tidak berbahaya berarti bahwa komoditas atau layanan tidak harus berbahaya bagi pihak-pihak tertentu atau masyarakat umum. Oleh karena itu, terlepas dari apakah transaksi tersebut dilakukan dalam perdagangan tradisional atau elektronik, kedua prasyaratan di atas harus dipenuhi oleh semua pelaku transaksi. Sejak E-Commerce dilakukan, layanan berbasis computer dan internet menjadi poin yang fundamental.

Ada kondisi tertentu yang harus diperhatikan untuk memastikan legalitas ECommerce dalam Islam. Pertama, harus ada kejelasan dalam komunikasi dan produk harus jelas didefinisikan, misalnya, gambar produk harus jelas ditampilkan pada layar, memberikan detail spesifikasi-spesifikasi, harga, modus pengiriman dan cara pembayaran. Kedua, kedua pihak kontraktor harus menerima konfirmasi pemesanan dalam perjanjian. Ketiga, harus ada kesinambungan dalam komunikasi, baik dalam transmisi pesan atau konsultasi antara satu sama lain melalui e-mail (Norazlina Zainul et. al, 2004 ).

Dalam etika berbisnis dalam Islam, ketulusan dan kejujuran adalah nilai yang paling mendasar. Seorang pengusaha harus jujur, jujur dan lugas dalam semua urusan bisnisnya. Tidak ada kecurangan, kebohongan, sumpah palsu dalam rangka Islam bisnis. 
Dalam kontrak secara umum, Islam mendifinisikannya sebagai kesepakatan kedua belah pihak untuk pemenuhan dari hal-hal tertentu yang tertuang pada kesepakatan dan persetujuan (ijab qabul).

Menurut sebagian ulama, ada empat pilar kontrak yang harus dipenuhi, pelaku akad, objek akad dan ijab qabul (Norazlina Zainul et. al, 2004). Pertama, pelaku akad harus memenuhi syarat kecakapan (al-Ahliyah). Kedua, kedua belah pihak harus mempunyai kapasitas dalam melakukan akad, dalam hal ini adalah aqil balig, mumayyiz dan memiliki pikiran yang sehat. Ketiga, objek akad harus berupa mal mutaqawwam, artinya pemanfaatnya boleh menurut syariat, di bawah kepemilikan, eksis dan dapat diterima. Keempat, ekspresi kedua belah pihak atas kehendak mereka dan bisa juga yang berupa ucapan, tindakan, tulisan dan isyarat yang menyatakan kerelaan (shigah) (Dziauddin, 2001). Sebagaimana disebutkan dalam Al-Quran (QS. Al-Baqarah[2]: 282),

"Hai orang-orang yang beriman, apabila kamu bermu'amalah tidak secara tunai untuk waktu yang ditentukan, hendaklah kamu menuliskannya. Dan hendaklah seorang penulis di antara kamu menuliskannya dengan benar. Dan janganlah penulis enggan menuliskannya sebagaimana Allah mengajarkannya, meka hendaklah ia menulis, dan hendaklah orang yang berhutang itu mengimlakkan (apa yang akan ditulis itu), dan hendaklah ia bertakwa kepada Allah Tuhannya, dan janganlah ia mengurangi sedikitpun daripada hutangnya. Jika yang berhutang itu orang yang lemah akalnya atau lemah (keadaannya) atau dia sendiri tidak mampu mengimlakkan, maka hendaklah walinya mengimlakkan dengan jujur. Dan persaksikanlah dengan dua orang saksi dari orang-orang lelaki (di antaramu). Jika tak ada dua oang lelaki, maka (boleh) seorang lelaki dan dua orang perempuan dari saksi-saksi yang kamu ridhai, supaya jika seorang lupa maka yang seorang mengingatkannya. Janganlah saksi-saksi itu enggan (memberi keterangan) apabila mereka dipanggil; dan janganlah kamu jeтu menulis hutang itu, baik kecil maupun besar sampai batas waktu membayarnya. Yang demikian itu, lebih adil di sisi Allah dan lebih menguatkan persaksian dan lebih dekat kepada tidak (menimbulkan) keraguanmu. (Tulislah mu'amalahmu itu), kecuali jika mu'amalah itu perdagangan tunai yang kamu jalankan di antara kamu, maka tidak ada dosa bagi kamu, (jika) kamu tidak menulisnya. Dan 
persaksikanlah apabila kamu berjual beli; dan janganlah penulis dan saksi saling sulit menyulitkan. Jika kamu lakukan (yang demikian), maka sesungguhnya hal itu adalah suatu kefasikan pada dirimu. Dan bertakwalah kepada Allah; Allah mengajarmu; dan Allah Maha Mengetahui segala sesuatu."

Dalam kaitannya dengan E-commerce, ada tiga (3) jenis kontrak yang sering digunakan, yaitu: bai salam, bai' istisna' dan bai' mu'ajjal. Bai salam adalah kontrak penjualan di mana harga dibayar penuh di muka sementara produk akan dikirimkan kemudian (Dziauddin, 2001). Al Quran telah membuktikan legalitas kontrak ini. Selain itu, ada satu hadis yang diriwayatkan oleh Ibnu Abbas yang menyatakan: Ketika Nabi datang ke Madinah, orang-orang yang membuat salam (memerintahkan) penjualan panen masa depan buah mereka (dalam satu, dua dan tiga tahun). Rasulullah Bersabda:"Siapapun yang ingin membuat penjualan salam, melakukannya pada barang yang spesifik dan untuk jangka waktu yang telah ditetapkan waktu”.

Adapun syarat yang harus dipernuhi dalam bai' salam ini adalah: 1) Barang yang diperjual belikan harus spesifik. 2) Barang diserahkan kemudian dan dalam waktu yang telah disepakati. 3) Harus tersedia di pasar (mal mistly). 4) Pembayaran harus lunas di awal kontrak

Bai' istisna' adalah suatu bentuk akad jual beli di mana pembeli memberikan perintah untuk seorang pekerja (penjual) untuk membuat barang tertentu dengan kesepakatan untuk membayar upah atau harga untuk hal yang ketika itu dibuat. Akad ini mirip dengan jual beli salam karena itu juga objek yang diperjualbelikan juga diserahkan kemudian; hanya saja pembayaran tidah harus dilunasi di awal kontrak, dan juga barang yang diperjual belikan tidak tersedia di pasar (Dziauddin, 2001).

Bai bi-tsaman 'ajil (BBA) adalah kontrak penjualan di mana kedua belah pihak setuju bahwa pembayaran harga untuk produk tersebut ditangguhkan sedangkan barang yang diperjual belikan diserahkan pada di awal akad. Al-Quran yang membuktikan legalitas kontrak ini.

E-Commerce merupakan aplikasi dari salah satu dari tiga jenis kontrak yang telah disebutkan di atas, tergantung pada modus komunikasi dan jenis usaha yang dilakukan. Ketika sebuah perusahaan yang melakukan penjualan on-line 
mengharuskan pelanggan melakukan pembayaran di awal dan barang yang diperjualbelikan diserahkan kemudian, maka itu adalah bai salam. Jika perusahaan membuat kesepakatan dengan pelanggan untuk menghasilkan produk yang dipesan dan pelunasannya hanya setelah produk dibuat maka transaksi itu adalah bai istishna. Dan jika perusahaan setuju untuk menjual komoditasnya kepada pelanggan dengan harga ditangguhkan atau angsuran, maka itu adalah bai' bi tsaman 'ajil.

Menurut Ustaz Mustafa Omar (Norazlina Zainul et. al, 2004), awalnya ada lima tahap yang direkomendasikan oleh Islam untuk memastikan validitas ecommerce. Antara lain:

1) Memulai kontrak (At-Ta'aqut).

Ini adalah tahap pertama dari memulai kontrak on-line di mana semua pilar dalam kontrak telah dipenuhi. Dalam hal ini, persyaratan pelaku akad telah dipenuhi, barang yang diperjualbelikan serta harga yang telah sesuai dengan prinsip Islam, dan ijab qabul. Pihak yang menjual dalam hal ini adalah perusahaan harus betul betul bisa dipastikan eksistensinya dan telah memiliki reputasi yang baik, serta memilki izin operasioanl yang masih berlaku.

2) Konfirmasi validitas

Setelah semua rukun beserta syaratnya telah dipenuhi, maka langkah yang harus diambil adalah memastikan kontrak harus bebas dari unsurunsur yang diharamkan seperti Riba, Gharar Fahisy (ketidakpastian yang merugikan pihak pembeli) Penipuan, paksaan, setiap unsur judi (maysir).

3) Pelaksanaan (Nafath)

Di mana pihak pembeli memulai prosuder pemesanan serta melakukan pembayaran sesuai dengan pilihan yang ia buat.

4) Binding (Ilzham)

Dalam tahap ini, kedua belah pihak kontraktor harus terikat atas kesepakatan yang telah dibuat. Baik penjual maupun pembeli tidak boleh membatalkan pembelian secara sepihak. 
5) Pengiriman objek jual beli

Pihak penjual mengirimkan barang yang telah dipesan sesuai dengan alamat yang telah dicantumkan pada saat pemesanan. Pembayaran telah dilakukan sesuai dengan pilihan yang juga telah dicantumkan.

\section{Konsep Khiyar}

Meskipun barang yang diperjual belikan dalam transaksi e-commerce telah jelas dispesifikan dan telah jelaskan secara detail, namun resiko ketidakcocokan dan kerugian yang akan dialami oleh pembeli masih memungkinkan terjadi. Olehkerena itu, dalam transaksi ini, pihak penjual memberikan hak kepada pembeli untuk mengembalikan barang dan menerima pembayarannya atau menukarkan barang tersebut sesuai dengan ketentuan yang telah disepakati sebelumnya. Dalam hal ini, konsep hak pengembalian dan penukaran tersebut sejalan dengan konsep khiyar dalam Islam.

Secara terminologi, khiyar berasal dari akar kata arab yaitu, "khara-yakhirukhairan-wa khiyaratan”. Sedangkan secara terminology, kalangan fuqaha, mendefiniskannya sebagai usaha untuk memilih yang terabaik akibatnya dari dua pilihan baik, dalam konteks ini berupa menlanjutkan transaksi atau membatalkannya (Aziz Azam, 1993)

Sayyid Sabiq mendefinisika khiyar sebagai upaya untuk menuntut yang terbaik dari dua perkara, berupa meneruskan (akad jual beli) atau membatalkannya.

Khiyar itu dimaksudkan untuk menjamin adanya kebebasan berpikir antara pembeli dan penjual atau salah seorang yang membutuhkan khiyar. Akan tetapi oleh karena dengan sistem ini ada kalanya menimbulkan penyesalan kepada salah seorang dari pembeli atau penjual yaitu kalau pedagang mengharap barangnya segera laku, tentu tidak senang kalau barangnya dikembalikan lagi sesudah jual beli atau kalau pembeli sangat mengharapkan mendapat barang yang dibelinya, tentu tidak senang hatinya kalau uangnya dikembalikan lagi sesudah akad jual beli. Maka oleh karena itu, untuk menetapkan syahnya ada khiyar harus ada ikrar dari kedua belah pihakatau salah satu pihak yang diterima oleh pihak lainnya atau kedua pihaknya, kalau kedua belah pihak menghendakinya (Sudarsono, 1992) 
Dari definisi yang telah dikemukakan di atas dapat disimpulkan bahwa khiyar adalah pilihan untuk melanjutkan jual beli atau membatalkannya, karena terdapat cacat terhadap barang yang dijual, atau ada perjanjian pada waktu akad, atau karena sebab yang lain. Adapun tujuannya adalah untuk mewujudkan kemaslahatan bagi kedua belah pihak sehingga tidak ada rasa menyesal setelah akad selesai, karena mereka sama-sama rela atau setuju. (Ahmad Wardi Muslich)

Berdasarkan prinsip wajib menegakkan kejujuran dan kebenaran dalam perdagangan, maka haram bagi penjual menyembunyikan cacat barang. Apabila dalam barang yang akan dijual itu terdapat cacat yang diketahui oleh pemilik barang (penjual), maka wajiblah dia menerangkan hal itu dan tidak boleh menyembunyikannya. Menyembunyikan cacat barang dengan sengaja termasuk penipuan dan kecurangan. (Hamzah Yaqub. 1992)

Khiyar hukumnya mubah berdasarkan sabda Rasulullah saw. Yang berbunyi : Dari Abdullah bin al-harits ia berkata: saya mendengar Hakim bin Hizam r.a dari Nabi saw beliau bersabda: "Penjual dan pembeli boleh melakukan khiyar selama mereka berdua belum berpisah. Apabila mereka berdua benar dan jelas, maka mereka berdua diberi keberkahan didalam jual beli mereka, dan apabila mereka berdua berbohong dan merahasiakan, maka dihapuslah keberkahan jual beli mereka berdua”. ( HR. Al-Bukhari).

Dari hadis tersebut jelaslah bahwa khiyar dalam akad jual beli hukumnya dibolehkan. Apalagi apabila dalam barang yang dibeli terdapat cacat (aib) yang bisa merugikan kepada pihak pembeli. Hak khiyar ditetapkan oleh syari'at Islam bagi orang-orang yang melakukan transaksi agar tidak dirugikan dalam transaksi yang mereka lakukan, sehingga kemaslahatan yang dituju dalam suatu transaksi tercapai dengan sebaik-baiknya. Status khiyar, menurut ulama fiqih adalah disyari'atkan atau dibolehkan karena masing-masing pihak yang melakukan transaksi supaya tidak ada pihak yang merasa tertipu (Gemala Dewi, 2005)

\section{Jenis-jenis Khiyar}

Ada banyak jenis khiyar dalam Islam, namun dalam tulisan ini penulis memfokuskan hanya pada empat (4) macam khiyar saja, yaitu; 


\subsection{Khiyar Majlis}

Majlis secara bahasa adalah bentuk masdar mimi dari julus yang berarti tempat duduk, dan maksud dari majlis akad menurut kalangan ahli fiqih adalah tempat kedua orang yang berakad berada dari sejak mulai berakad sampai sempurna, berlaku dan wajibnya akad. Dengan begitu majlis akad merupakan tempat berkumpul dan terjadinya akad apapun keadaan pihak yang berakad.

Adapun menurut istilah khiyar majlis adalah khiyar yang ditetapkan oleh syara' bagi setiap pihak yang melakukan transaksi, selama para pihak masih berada di tempat transaksi. Khiyar majelis berlaku dalam berbagai macam jual beli, seperti jual beli makanan dengan makanan, akad salam (Wahbah zuhaily, 2010).

Khiyar ini diperbolehkan sebagaimana Rasulullah Saw. Bersabda, "Penjual dan pembeli boleh melakukan khiyar selama keduanya belum berpisah, atau salah seorang mengatakan kepada temannya: "Pilihlah". Dan kadang-kadang beliau bersabda: "Atau terjadi jual beli khiyar". (HR. AlBukhari).

Ketika jual beli telah berlangsung, masing-masing pihak berhak melakukan khiyar antara membatalkan atau meneruskan akad hingga mereka berpisah atau menentukan pilihan. Perpisahan terjadi apabila kedua belah pihak telah memalingkan badan untuk meninggalkan tempat transaksi. Pada prinsipnya khiyar majlis berakhir dengan adanya dua hal: pertama, keduanya memilih akan terusnya akad. Kedua, diantara keduanya terpisah dari tempat jual beli.

\subsection{Khiyar Syarat}

Menurut Sayyid Sabiq, khiyar syarat adalah suatu khiyar dimana seseorang membeli sesuatu dari pihak lain dengan ketentuan dia boleh melakukan khiyar pada masa atau waktu tertentu, walaupun waktu tersebut lama, apabila ia menghendaki maka ia bisa melangsungkan jual beli dan apabila ia mengendaki ia bisa membatalkannya. Dari definisi tersebut dapat dipahami bahwa khiyar syarat adalah suatu bentuk khiyar dimana para pihak yang melakukan akad jual beli memberikan persyaratan bahwa dalam waktu 
tertentu mereka berdua atau salah satunya boleh memilih antara meneruskan jual beli atau membatalkannya.

Dasar hukum khiyar syarat adalah hadist yang diriwayatkan oleh Bukhari Muslim, Dari Ibnu Umar r.a dari Rasulullah saw beliau bersabda:

"Apabila dua orang melakukan jual beli, maka masing-masing pihak berhak melakukan khiyar, baik kedua-duanya maupun salah satunya. Apabila salah satu dari keduanya melakukan khiyar terhadap yang lainnya, kemudian mereka berdua melakukan jual beli atas dasar kesepakatan mereka, maka jual beli telah wajib dilaksanakan. Apabila mereka berpisah setelah melakukan jual beli dan salah satu pihak tidak meninggalkan jual beli, maka jual beli wajib dilaksanakan”. (HR. Muttafaq 'Alaih)

Khiyar syarat disyari'atkan untuk menjaga kedua belah pihak yang berakad, atau salah satunya dari konsekuensi satu akad yang kemungkinan di dalamnya terdapat unsur penipuan dan dusta. Oleh karena itu, Allah SWT memberi orang yang berakad dalam masa khiyar syarat dan waktu yang telah ditentukan satu kesempatan untuk menunggu karena memang diperlukan.

\subsection{Khiyar 'Aib}

Khiyar 'aib termasuk dalam jenis khiyar naqishah (berkurangnya nilai penawaran barang). Khiyar aib berhubungan dengan ketiadaan kriteria yang diduga sebelumnya. Khiyar aib merupakan hak pembatalan jual beli dan pengembalian barang akibat adanya cacat dalam suatu barang yang belum diketahui, baik aib itu ada pada waktu transaksi atau baru terlihat setelah transaksi selesai disepakati sebelum serah terima barang.

Yang mengakibatkan terjadinya khiyar disini adalah cacat (aib) yang mengakibatkan berkurangnya harga dan nilai bagi para pedagang dan orangorang yang ahli dibidangnya. Menurut ijma' Ulama, pengembalian barang karena cacat boleh dilakukan pada waktu akad berlangsung, sebagaimana yang diterangkan dalam suatu hadis yang berasal dari penuturan 'Uqbah bin Amir R.a, "Aku mendengar Rasulullah bersabda: Seorang muslim adalah saudaranya muslim lainnya, tidak halal bagi seorang muslim apabila menjual barang jualannya kepada muslim lain yang didalamnya ada cacat, melainkan ia harus menjelaskan (aib atau cacatnya) itu kepadanya”. ( HR. Al-Hakim) 
Jika akad telah dilakukan dan pembeli telah mengetahui adanya cacat pada barang tersebut, maka akadnya sah dan tidak ada lagi khiyar setelahnya. Alasannya ia telah rela dengan barang tersebut beserta kondisinya. Namun jika pembeli belum mengetahui cacat barang tersebut dan mengetahuinya setelah akad, maka akad tetap dinyatakan benar dan pihak pembeli berhak melakukan khiyar antara mengembalikan barang atau meminta ganti rugi sesuai dengan adanya cacat.

Dimyauddin Djuwaini mengatakan bahwa khiyar 'aib bisa dijalankan dengan syarat sebagai berikut:

1) Cacat sudah ada ketika atau setelah akad dilakukan sebelum terjadi serah terima, jika aib muncul setelah serah terima maka tidak ada khiyar.

2) Cacat tetap melekat pada obyek setelah diterima oleh pembeli.

3) Pembeli tidak mengetahui adanya cacat atas obyek transaksi, baik ketika melakukan akad atau setelah menerima barang. Jika pembeli mengetahui sebelumnya, maka tidak ada khiyar karena itu berarti pembeli telah menerima kecacatan barang.

4) Tidak ada persyaratan bara'ah (bebas tanggungan) dari cacat dalam kontrak jual beli, jika dipersyaratkan, maka hak khiyar gugur.

5) Cacat masih tetap sebelum terjadinya pembatalan akad. Pembeli diperbolehkan memilih antara mengembalikan yang telah dibeli dan mengambil harganya, atau tetap menahan barang tersebut tanpa memperoleh ganti apapun dari pihak penjual. Jika kedua belah pihak sepakat bahwa pembeli tetap membawa barang yang dibelinya sedang penjual memberikan ganti rugi cacatnya kebanyakan fuqaha membolehkannya ( Abdul Wahid, 2007) 


\section{Aplikasi Khiyar dan ketentuannya pada blibli.com, Lazada dan Zalora}

\subsection{Blibli.com}

Cara pengembalian dan penukaran produk-produk yang telah dibeli dari www.blibli.com dilakukan sesuai dengan ketentuan-ketentuan yang tercantum dalam kebijakan pengembalian (return policy) yang ditetapkan oleh masingmasing penjual (merchant) produk-produk. Secara umum, Blibli.com hanya menerima pengembalian produk cacat produksi. Produk yang akan dikembalikan harus dalam kondisi baru dan belum digunakan. Untuk produk-produk yang dilengkapi dengan segel garansi, Segel garansi tersebut harus dalam keadaan utuh.

Blibli.com memfasilitasi proses pengembalian atau penukaran produk yang telah dibeli dengan menyediakan halaman return policy. Pada halaman yang disediakan, pembeli dapat melaporkan kerusakan produk dengan memberikan foto dan deskripsi singkat mengenai kerusakan produk tersebut dalam kurun $1 \times 24$ jam dari waktu Anda menerima produk. Laporan kerusakan harus disertai dengan nomor pemesanan (order number).

Setelah permintaan pengembalian (return request) diterima dan diproses oleh customer service center blibli, maka customer service akan segera menghubungi pembeli melalui alamat surat elektronik (email) atau telepon untuk mengkonfirmasikan return request. Apabila return request disetujui, customer service akan memberikan informasi mengenai metode pengiriman produk yang dikembalikan (Blibli dilihat pada 30 Nov 2015)

\subsection{Zalora}

Pada transaksi jual beli on-line zalora, pembeli menghubungi customer service untuk mengonfirmasi pengembalian barang dan kemudian mengisi formulir penukaran dan pengembalian yang disertakan pada produk tersebut. Produk harus dikembalikan dalam jangka waktu garansi 7 hari. Waktu garansi terhitung sejak saat pembeli menerima pesanan. Uang akan dikembalikan dalam waktu 1 hari kerja jika menggunakan credit card, rekening BCA, Mandiri atau BRI dan jika menggunakan rekening bank lain nya paling lambat 3 hari kerja, terhitung sejak barang diterima kembali.

Adapun syarat dan ketentuan pengembalian atau penukaran barang antara lain; 
1) Barang yang ingin dikembalikan harus dalam kondisi yang sama seperti pada saat diantarkan, termasuk kemasannya.

2) Produk tidak boleh dalam keadaan rusak, kotor atau telah dicuci.

3) Label harga dan barcode barang masih dalam keadaan utuh.

4) Kembalikan beserta kemasan aslinya dan tas (bila diberikan).

Dengan berbagai bentuk pengecualian sebagai berikut:

1) Pengembalian barang tidak berlaku untuk pakaian dalam, produk kecantikan, dan perhiasan.

2) Jika pembeli menggunakan voucher pada saat pembelian, nilai voucher tidak dapat dikembalikan.

3) Semua barang yang dibeli dengan nilai promo 50\% ke atas tidak dapat dikembalikan.

4) Biaya pengiriman tidak dapat dikembalikan kecuali kesalahan pengiriman oleh pihak Zalora (zalora.co.id dilihat pada 30 Nov 2015)

\subsection{Lazada}

Tidak jauh berbeda dengan situs di atas, proses pengembalian di lazada dimulai dengan melakukan log in pada situs tersebut. Setelah itu mencari "My Order" kemudian mengklik return. Dalam laman tersebut, pembeli mengisi formulir pengembalian secara online, mencetaknya dan kemudian mengirimkannya bersamaan dengan produk yang ingin ditukar atau dikembalikan. Dapat kita ilustrasikan sebagai berikut

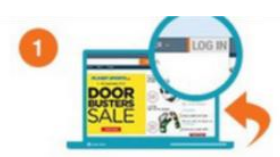

Login ke akun anda
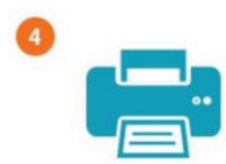

Cetak formulir retur (Pilihan)

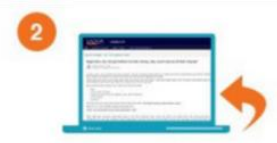

Klik ke My Order dan klik Return

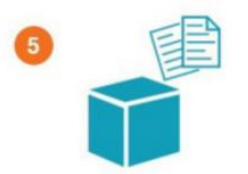

Kemas barangnya dan lampirkan return label

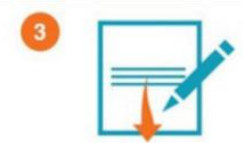

Isi formulir retur online

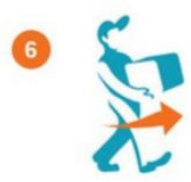

Kirimkan ke Lazada

Apabila Anda tidak dapat mengakses Formulir Pengembalian Online karena satu dan lain hal, Anda dapat menghubungi Customer Service kami [klik disini]. Kami senang untuk membantu pengembalian Anda. 
Adapun syarat dan ketentuan pengembalian

\begin{tabular}{|l|c|c|c|c|c|}
\hline \multirow{2}{*}{\multicolumn{1}{|c|}{ Alasan Pengembalian }} & \multicolumn{5}{c|}{ Pengembalian Barang Anda Harus: } \\
\cline { 2 - 6 } & Baru & $\begin{array}{c}\text { Masih } \\
\text { Disegel }\end{array}$ & $\begin{array}{c}\text { Lengkap (hadiah gratis, } \\
\text { aksesoris, dus asli) }\end{array}$ & $\begin{array}{c}\text { Tidak } \\
\text { rusak }\end{array}$ & $\begin{array}{c}\text { Tag \& label } \\
\text { tertera }\end{array}$ \\
\hline Rusak & $\mathrm{x}$ & $\mathrm{x}$ & $\checkmark$ & $\mathrm{x}$ & $\checkmark$ \\
\hline Cacat & $\mathrm{x}$ & $\mathrm{x}$ & $\checkmark$ & $\checkmark$ & $\checkmark$ \\
\hline $\begin{array}{l}\text { Tidak muat (untuk produk fashion) } \\
\text { *TIDAK BERLAKU untuk produk } \\
\text { Internasional }\end{array}$ & $\checkmark$ & $\mathrm{x}$ & $\checkmark$ & $\checkmark$ & $\checkmark$ \\
\hline Tidak sesuai dengan website & $\checkmark$ & $\mathrm{x}$ & $\checkmark$ & $\checkmark$ & $\checkmark$ \\
\hline Salah/item yang salah & $\checkmark$ & $\mathrm{x}$ & $\checkmark$ & $\checkmark$ & $\checkmark$ \\
\hline Produk/bagian hilang & $\checkmark$ & $\mathrm{x}$ & $\mathrm{x}$ & $\checkmark$ & $\checkmark$ \\
\hline $\begin{array}{l}\text { Berubah pikiran* } \\
\text { *Hanya berlaku untuk 100\% Jaminan } \\
\text { Kepuasan }\end{array}$ & $\checkmark$ & $\checkmark$ & $\checkmark$ & $\checkmark$ & $\checkmark$ \\
\hline
\end{tabular}

CATATAN: Apabila pengembalian barang Anda dinyatakan tidak sah, Customer Service kami akan menghubungi Anda sebelum mengembalikannya kembali kepada Anda. Biaya pengiriman barang Anda tidak akan diganti.

(Lazada.co.id dilihat pada 30 Nov 2015)

\section{Perbandingan konsep khiyar pada tiga took on-line}

Setelah proses dan ketentuan pengembalian telah dipaparkan di atas, kita dapat membandingkan aplikasi khiyar pada ketika situs e-commerce sebagai berikut:

\begin{tabular}{|c|c|c|c|}
\hline Jenis Khiyar & Blibli & Zalora & Lazada \\
\hline Khiyar Majlis & tidak & tidak & Tidak \\
\hline Khiyar Syarat & tidak & Tidak & tidak \\
\hline Khiyar Aib & Ya & Ya & Ya \\
\hline Khiyar Ru'yah & tidak & tidak & Ya \\
\hline
\end{tabular}

Jadi khiyar aib diaplikasikan oleh seluruh ketiga situs tersebut, sedangkan lazada lah yang satu satunya mengaplikasikan khiyar ru'yah.

\section{Kesimpulan}

Khiyar merupakan instrumen yang sangat diperlukan dalam transaksi $e$ commerce. Khiyar memberikan pilihan kepada pembeli menukarkan dan mengembalikan barang yang telah diterima yang ketentuannya telah diatur oleh masing masing penjual. Ada empat (4) jenis khiyar yang ditengahkan dalam penelitian ini. Dan hanya khiyar aib yang diaplikasikan oleh blibli, zalora dan lazada. 


\section{Daftar Pustaka}

Ibnu Rusyd, Abdul Wahid Muhammad. 2007. Bidayatul Mujtahid, Terj. Ghazali Said, (Jakarta: Pustaka Amani)

Ahmad, Dziauddin. 2001. The Theory of Riba,

Muhammad Azzam, Abdul Aziz. 2010. Fiqh Muamalat Sistem Transaksi dalam Fiqh Islam, (Jakarta: Amzah)

Muslich, Ahmad Wardi. 2010. Fiqh Muamalat, (Jakarta: Amzah)

Ya'qub, Hamzah. 1992. Kode Etik Dagang Menurut Islam (Pola Pembinaan Hidup dalam Berekonomi), (Bandung: CV. Diponegoro)

Husnayati, Hussin. 2002. E-Commerce: Exploring Some Issues from the Islamic Perspective.

Sudarsono, Heri. 1992. Pokok-pokok Hukum Islam, (Jakarta: Rineka Cipta)

Thomas R. Leinbach, Stanley D. Brunn, 2001.Worlds of E- Commerce: Economic, Geographical and Social Dimensions, (England: Wiley)

Qardhawi,Yusuf. 1993. Al-Halal Wa Haram fil Islam, Terj. Mu'ammal Hamidy, (Jakarta: Bina Ilmu)

Zuhaili, Wahbah. 2010. Cet. I, Al-Fiqhu As-Syafi'i Al-Muyassar, Terj. Muhammad Afifi, Abdul Hafiz, (Jakarta: Almahira)

Zainul et al., E-Commerce in Islamic Perspective, Electronic Commerce Research and Applications 3 (2004)

http://www.blili.com

http://www.zalora.co.id

http://www.lazada.co.id 